\title{
Erratum to: The relationship of recombination rate, genome structure, and patterns of molecular evolution across angiosperms
}

George P. Tiley ${ }^{*}$ and J. Gordon Burleigh

\section{Erratum}

The original version of this article [1] unfortunately contained a mistake. The author list was presented with a mistake, Dr J. Gordon Burleigh was incorrectly listed as "Gordon Burleigh" in both the PDF and HTML versions of this manuscript. The corrected author list is provided below:

George P. Tiley* and J. Gordon Burleigh

The original article [1] was updated to reflect this change.

Received: 27 October 2015 Accepted: 28 October 2015

Published online: 09 November 2015

\section{Reference}

1. Tiley GP, Burleigh JG. The relationship of recombination rate, genome structure, and patterns of molecular evolution across angiosperms. BMC Evol Biol. 2015;15:194. doi:10.1186/s12862-015-0473-3.

*Correspondence: gtiley@ufl.edu

Department of Biology, University of Florida, Bartram-Carr Hall, Gainesville 32611, FL, USA
Submit your next manuscript to BioMed Central and take full advantage of:

- Convenient online submission

- No space constraints or color figure charges

- Immediate publication on acceptance

- Inclusion in PubMed, CAS, Scopus and Google Scholar

- Research which is freely available for redistribution

Submit your manuscript at www.biomedcentral.com/submit 